\title{
Permainan Augmented reality dalam Mendukung Pembelajaran Anak tentang Binatang pada Perangkat iOS
}

\author{
Radhea Wicaksono Putra, Darlis Herumurti, dan Imam Kuswardayan \\ Jurusan Teknik Informatika, Fakultas Teknologi Informasi, Institut Teknologi Sepuluh Nopember (ITS) \\ Jl. Arief Rahman Hakim, Surabaya 60111 Indonesia \\ e-mail: darlis@if.its.ac.id
}

\begin{abstract}
Abstrak-Kebun binatang adalah tempat untuk menampung beragam jenis binatang yang dapat kita lihat langsung dan juga tempat wisata yang tepat untuk keluarga, apalagi bersama anakanak. Mereka dapat belajar banyak tentang binatang. Namun waktu bisa jadi kendala bagi orang tua karena tidak sempat membawa anak mereka pergi kesana, sehingga belum ada kesempatan bagi anak-anak untuk mengenal lebih tentang binatang. Augmented reality merupakan salah satu solusi untuk mengatasi masalah tersebut. Pembelajaran tentang binatang akan ditampilkan dalam bentuk realitas augmentasi. Lingkungan, binatang, objek, dan keadaan yang mendukung proses pembelajaran akan diubah ke dalam bentuk 3 dimensi yang menyerupai aslinya. Tugas akhir ini bertujuan untuk membuat sebuah permainan Augmented reality pembelajaran anak-anak tentang binatang. Pengujian dilakukan dengan bantuan marker sebagai penempatan objek tiga dimensi dan suara yang berupa pertanyaan. Pengguna menyelesaikan beberapa skenario pembelajaran seperti menghitung, mencari, dan memilih binatang dengan menggunakan iPad. Pengukuran hasil uji dibantu dengan kuesioner untuk menilai tingkat kepuasan dalam proses pembelajaran.
\end{abstract}

Kata Kunci-Augmented reality, iOS, Kebun Binatang

\section{PENDAHULUAN}

A NAK-ANAK pada dasarnyna suka bermain dan secara tidak langsung diikuti dengan belajar dengan harapan mendapat pengalaman lebih. Kebun binatang merupakan tempat yang tepat untuk anak-anak dalam belajar dan bermain dengan lingkungan, memberikan banyak informasi yang bermanfaat tentang binatang beserta perilakunya. Kebun binatang juga salah satu tempat yang sering dikunjungi sebagai tempat rekreasi, namun tidak sedikit orang tua yang bisa mengajak anaknya karena kendala waktu dan akomodasi. Orang tua perlu tahu bahwa anak-anak butuh bermain dan juga belajar di alam terbuka, mengenal makhluk hidup sekitar.

Maka dari itu dibutuhkan sebuah media pendukung yang dapat membantu anak- anak dalam bermain dan sekaligus belajar tentang lingkungan terbuka, terutama kebun binatang dan perilaku binatang-binatang sebagai pembelajaran. Teknologi Augmented reality salah satu teknologi yang tepat dan dalam menggambarkan objek-objek dalam bentuk tiga dimensi yang dapat dikembangkan menjadi hal yang menarik, dikombinasikan dengan teknologi layar sentuh untuk berinteraksi dengan sistem.

Dalam penerapan permainan Augmented reality ini, digunakanlah sebuah marker dan iPad untuk memproyeksikan objek tiga dimensi. Terdiri dari beberapa skenario pembelajaran yang harus diselesaikan pengguna. Marker berperan dalam memposisikan objek animasi kedalam layar sentuh yang dipakai dan juga bantuan berupa suara.

Dari permainan Augmented reality kebun binatang ini diharapkan dapat membantu anak-anak dalam belajar sekaligus bermain dengan binatang-binatang tanpa harus pergi ke kebun binatang. Selain itu, anak-anak juga perlu berpikir dan bergerak agar dapat menjawab pertanyaan yang disediakan dalam permainan sehingga memiliki informasi dan nilai edukasi tentang binatang.

\section{TINJAUAN PUSTAKA}

\section{A. Augmented reality}

Augmented reality (AR) adalah teknologi yang menggabungkan objek dua atau tiga dimensi yang digambarkan dan diproyeksikan bersamaan dengan alam nyata secara real time. Augmented reality memanfaatkan fitur gyroscope dan accelerometer dalam memproyeksikan objek sehingga dapat dilihat dari sudut manapun, meningkatkan persepsi seseorang, tidak terganggu oleh lingkungan nyata, dan bahkan beradaptasi dengannya [1]. Saat ini hasil pengembangan Augmented reality menjadi lebih interaktif dan menarik, sebagai contoh dalam hal kesehatan, manufaktur, hiburan, dan navigasi yang membuat pengguna lebih memahami dunia teknologi yang hampir mendekati nyata tersebut.

\section{B. Unity}

Unity 3D adalah sebuah perangkat lunak yang berfungsi untuk membangun permainan atau aplikasi. Unity merupakan suatu game development ecosystem yang mampu digunakan untuk membuat permainan atau aplikasi dalam berbagai macam platform baik console, desktop, dan mobile. Bahasa pemrograman utama Unity adalah C\# dengan IDE Mono Develop. Unity menyediakan berbagai pilihan bahasa pemrograman untuk mengembangkan game, antara lain JavaScript, C Sharp (C\#), dan BooScript. Dalam penelitian ini penulis menggunakan bahasa pemrograman C Sharp (C\#) 
untuk mengembangkan aplikasi [2].

\section{Vuforia}

Vuforia Software Development Kit (SDK) untuk perangkat mobile untuk pembuatan aplikasi menggunakan teknologi Augmented reality. Terdapat Vuforia SDK sebagai package dalam Unity. Vuforia SDK membantu mengkombinasikan kamera pada merangkat mobile sebagai informasi masukan, sebagai mata elektronik yang mengenali penanda tertentu sehingga dapat muncul objek animasi di kehidupan nyata. Vuforia adalah SDK untuk computer-vision based Augmented reality, memiliki interaksi tanpa batas karena dapat dikembangkan dalam teknologi dua dimensi maupun tiga dimensi [3].

\section{XCode}

Xcode adalah sebuah IDE (Integrated Development Environment) yang berisi seperangkat alat pengembangan perangkat lunak yang dikembangkan oleh Apple untuk mengembangkan perangkat lunak OS X, iOS, Watch OS, dan tvOS. Xcode pertama kali rilis pada tahun 2003 dan versi terbarunya adalah 7.3. XCode bisa diunduh melalui Mac App Store secara gratis untuk pengguna OS. Xcode dapat menggunakan Bahasa pemrograman $\mathrm{C}, \mathrm{C}++$, Objective-C, Java, AppleScript, Python, Ruby, Cocoa, dan Swift. Ada pula fitur tambahan yakni GNU Pascal, Free Pascal, C\#, Perl, dan D. Xcode juga bertindak sebagai compiler untuk melakukan building cross-platform seperti Unity, sehingga aplikasi hasil pengembangan dari Unity dapat dijalankan di perangkat Apple lewat Xcode [4].

\section{E. iPad Mini Retina Display}

iOS iPad Mini Retina 2 adalah salah satu produk buatan Apple yang cukup terkenal, berbentuk tablet dengan ukuran layar 7.9 inci. Layar yang didukung Retina Display memiliki resolusi layar 2048x1536 memberikan kepadatan layar yang cukup tinggi. iPad Mini 2 ini dibekali dengan prosesor A7 chip dengan arsitektur 64-bit yang membuat sistem menjadi lebih cepat dan sangat responsif. Daya tahan baterai bisa mencapai hingga 10 jam penggunaan. Pemanfaatan perangkat ini sangat banyak dengan didukung kamera depan 5MP AF berteknologi iSight 5 lensa dan belakang 1.2MP 720p HD sehingga banyak aplikasi yang dapat menggunakan fitur ini. Augmented reality jelas dapat dimainkan pada perangkat ini dengan lancar karena didukung sensor gyroscope dan accelerometer, sehingga aplikasi akan dapat dimainkan dengan sangat imersif.

\section{ANALISIS DAN PERANCANGAN}

\section{A. Domain Permasalahan}

Teknologi ini mulai berkembang seiring kebutuhan yang bisa dimanfaatkan, seperti rehabilitasi, diagnosa, dan juga sebagai pembelajaran. Pembelajaran menggunakan media digital mulai dilirik para pengembang, memanfaatkan teknologi augmented reality sebagai media interaktif salah satunya untuk pembelajaran anak-anak. Anak-anak pada dasarnya suka bermain dan secara tidak langsung diikuti dengan belajar.

Kebun binatang merupakan tempat yang tepat untuk anakanak dalam belajar dan bermain dengan lingkungan, memberikan banyak informasi yang bermanfaat tentang binatang beserta perilakunya. Kebun binatang juga salah satu tempat yang sering dikunjungi sebagai tempat rekreasi, namun tidak sedikit orang tua yang bisa mengajak anaknya karena kendala waktu dan akomodasi. Orang tua perlu tahu bahwa anak-anak butuh bermain dan juga belajar di alam terbuka, mengenal makhluk hidup sekitar.

Pemanfaatan teknologi Augmented reality akan membantu anak- anak dalam bermain dan sekaligus belajar tentang lingkungan terbuka, terutama binatang-binatang sebagai objek pembelajaran. Tugas akhir ini menjelaskan rancangan aplikasi tersebut, menampilkan objek-objek kebun binatang dalam bentuk tiga dimensi yang dapat dikombinasikan dengan teknologi layar sentuh untuk berinteraksi dengan sistem.dan diharapkan dapat membantu anak-anak dalam belajar sekaligus bermain dengan binatang-binatang tanpa harus pergi ke kebun binatang.

\section{B. Deksripsi Umum}

Aplikasi ini dapat melakukan pembelajaran tentang binatang. Pembelajaran yang ditawarkan meliputi pembelajaran membaca, berhitung, dan mencari sebagai variasi tingkatan. Sebelum bermain akan siberikan pilihan binatang yang dapat dimainkan. Kemudian aplikasi ini dapat menampilkan objek pada sebuah bantuan penanda atau marker. Marker akan bertugas memberikan area letak untuk memproyeksikan objek maya yang akan muncul dan dapat berinteraksi lewat layar iPad. Aplikasi yang akan dibuat juga dapat menampilkan suara dalam bentuk pertanyaan. suara tersebut sebagai alat bantu dalam memahami pertanyaan yang diberikan.

\section{Aktor}

Aktor yang menjadi pengguna sistem adalah anak-anak dengan rata-rata umur antara 5 hingga 10 tahun, yaitu anakanak yang sedang duduk di taman kanak-kanak atau di sekolah dasar. Anak-anak pada umumnya masih dalam tahap belajar membaca dan menghitung.

\section{Kasus Penggunaan}

Berdasarkan analisis yang dilakukan maka didapatkan tiga kasus penggunaan dalam sistem. Kasus penggunaan ini meliputi:

1. Memilih tingkat pembelajaran binatang

2. Menampilkan objek dengan bantuan marker

3. Membunyikan teks pertanyaan skenario

Arsitektur sistem dapat dilihat pada Gambar 1, sedangkan untuk kasus penggunaan dapat dilihat pada Gambar 2. 

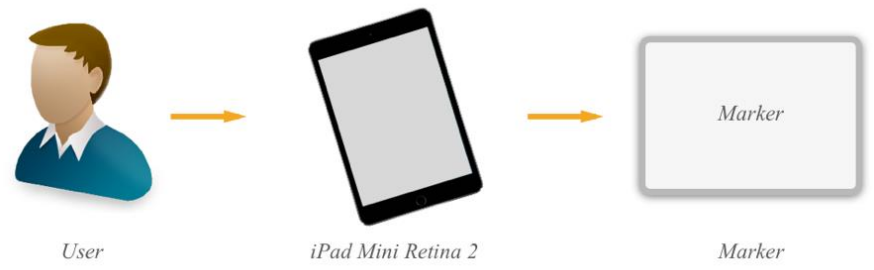

Gambar 1. Arsitektur Sistem

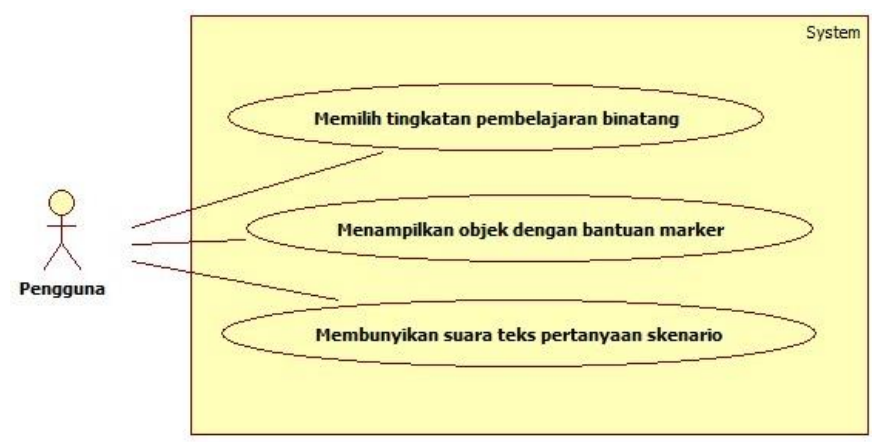

Gambar 2. Kasus Penggunaan

\section{IMPLEMENTASI}

\section{A. Lingkungan Implementasi}

Dalam merancang perangkat lunak ini digunakan beberapa perangkat pendukung yang terdiri dari perangkat keras dan perangkat lunak. Spesifikasi perangkat keras yang digunakan dalam membangun layanan pemesanan barang adalah sebagai berikut:

Jenis

Prosesor

: iPad Mini Retina Display 2

Memori

: Apple A7

$: 1 \mathrm{~GB}$

Sistem Operasi $\quad$ : iOS 9.3

Jenis $\quad:$ Komputer

Prosesor $\quad:$ Intel ${ }^{\circledR}$ Core $^{\mathrm{TM}}$ i5 $@ 2,60 \mathrm{GHz}$

Memori $: 8 \mathrm{~GB}$

Sistem Operasi: Mac OS X El Capitan 10.11.2

Perangkat lunak yang digunakan dalam membangun aplikasi Pembelajaran anak tentang binatang adalah sebagai berikut:

- Unity digunakan untuk menyunting kode;

- Adobe Illustrator digunakan untuk membangun antarmuka;

\section{B. Implementasi Antarmuka}

Antarmuka perangkat lunak dikembangkan menggunakan beberapa pustaka. Beberapa di antaranya adalah:

- Unity sebagai membangun aplikasi iOS;

- Vuforia SDK sebagai kakas bantu AR;

- Blender sebagai pembangun objek tiga dimensi;

- XCode sebagai kakas bantu untuk iPad;

- Audacity sebagai pengolah suara digital;

Halaman utama aplikasi pembelajaran dapat dilihat pada Gambar 3, untuk memilih tingkat pembelajaran dapat dilihat pada Gambar 4, dan halaman memilih binatang dapat dilihat pada Gambar 5.

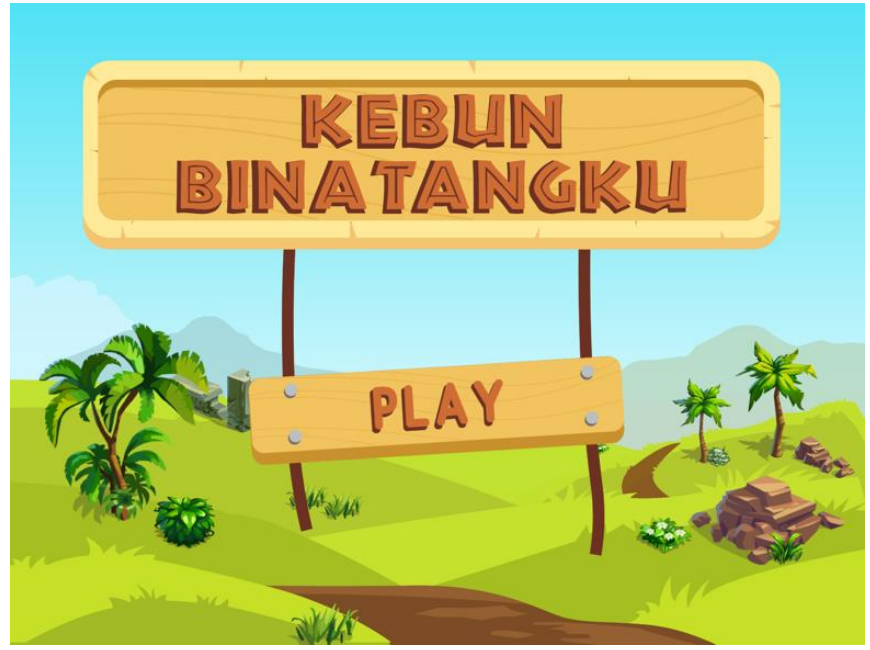

Gambar 3. Halaman Utama Aplikasi Pembelajaran

\section{LEVEL}

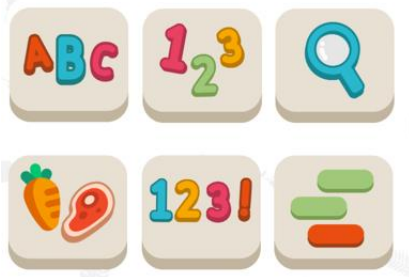

Gambar 4. Menu Memilih Tingkatan Pembelajaran

Terdapat 6 tingkatan pembelajaran yang dapat dimainkan, yaitu tingkatan menebak nama binatang, menghitung jumlah binatang yang dimainkan, mencari binatang, memilih makanan binatang, menghitung binatang selain yang dimainkan, dan memilih binatang yang muncul.

Pada tingkatan menebak nama binatang, akan muncul dua pilihan nama binatang yang salah satunya adalah jawaban yang benar. Halaman skenario menghitung binatang dapat dilihat pada Gambar 6. Pada halaman ini pengguna menghitung jumlah binatang yang muncul pada kebun binatang. Pengguna dapat menggunakan tombol tambah untuk menambah angka dan tombol kurang untuk mengurangi angka. Terdapat tombol jawab untuk mengecek jumlah binatang yang muncul. Jika jawaban kurang tepat maka pengguna dapat mengulangi tingkatan dan jika benar maka akan muncul panel bahwa jawaban benar dan dapat langsung kembali ke halaman memilih tingkatan. 


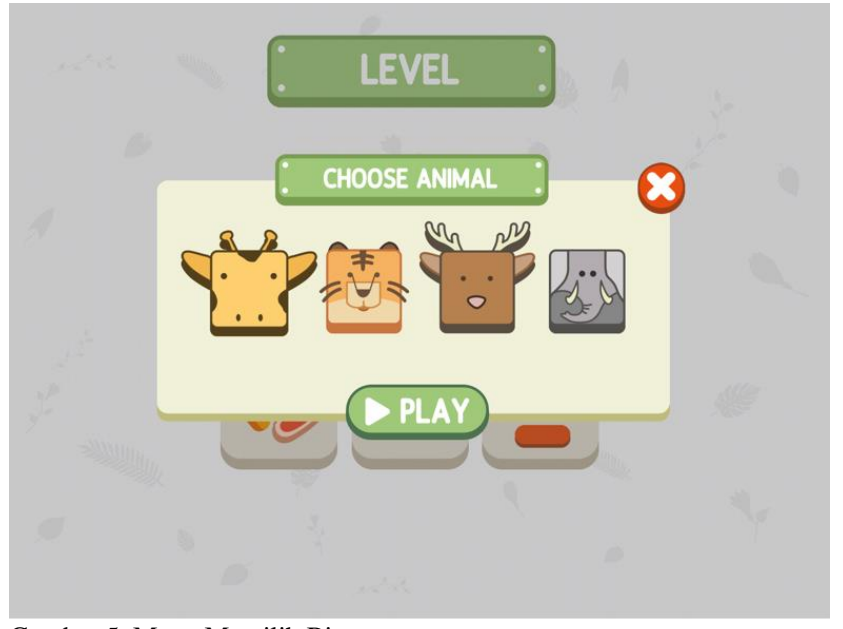

Gambar 5. Menu Memilih Binatang

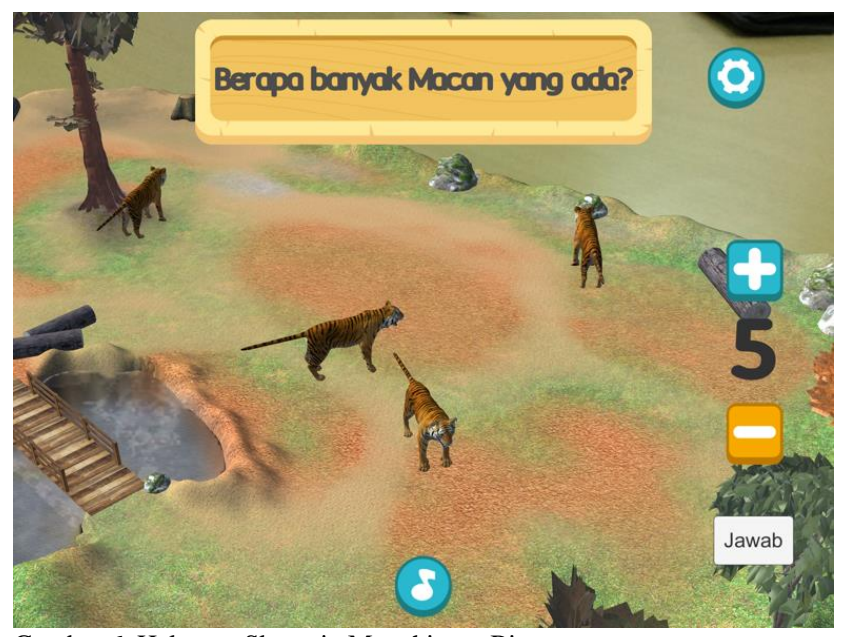

Gambar 6. Halaman Skenario Menghitung Binatang

\section{PENGUJIAN DAN EVALUASI}

Tuliskan kesimpulan dari penelitian yang artikelnya Anda tulis ini tanpa mengulang hal-hal yang telah disampaikan di Abstrak. Kesimpulan dapat diisi pula tentang pentingnya hasil yang dicapai dan saran untuk aplikasi dan pengembangannya.

\section{A. Skenario Pengujian}

Pengujian yang dilakukan adalah pengujian kebutuhan fungsionalitas. Pengujian fungsionalitas menggunakan metode kotak hitam (black box). Metode ini menekankan pada kesesuaian hasil keluaran sistem ditambah kepuasan pengguna.

Pengujian aplikasi dilakukan untuk mengetahui kesesuaian keluaran dari tiap tahap atau langkah penggunaan fitur terhadap skenario yang dipersiapkan. Pengujian dilakukan oleh 10 anak-anak dengan umur antara 5 hingga 10 tahun. Pada uji coba yang dilakukan, pengguna dapat memilih salah satu dari enam pilihan tingkatan pembelajaran untuk ditampilkan. Setelah sistem berhasil menampilkan halaman pemilihan tingkatan pembelajaran, pengguna dapat memilih binatang sesuai dengan binatang yang ingin dimainkan. Pada pengujian marker, pengguna mengarahkan kamera pada marker yang telah disediakan. Pengguna dapat bereksplorasi melihat objek binatang dari sisi manapun dan berinteraksi dengan objek.
Pada uji coba menyuarakan teks pertanyaan, pengguna menekan tombol yang tersedia pada halaman aplikasi. Suara yang muncul berupa suara pertanyaan yang sama dengan pertanyaan tulisan pada skenario dan pengguna dapat memahami pertanyaan yang diberikan.

\section{B. Evaluasi Pengujian}

Evaluasi yang diberikan meliputi evaluasi pengujian kebutuhan fungsional sebelumnya dan evaluasi pengujian kepuasan pengguna yang dilakukan sesuai dengan skenario dan prosedur yang telah didefinisikan sebelumnya. Berdasarkan data pada Tabel 1, seluruh skenario pengujian yang telah dilakukan berhasil, sedangkan untuk aplikasi yang dijalankan kurang baik karena kebutuhan memory aplikasi lebih dari memory perangkat yang ada sehingga terjadi crash.

Tabel 1

Evaluasi Pengujian Fungsionalitas

\begin{tabular}{clc}
\hline \hline ID & \multicolumn{1}{c}{ Nama } & Hasil \\
\hline UJ-P-01 & $\begin{array}{l}\text { Pengujian Memilih Tingkat Pembejaran } \\
\text { tentang Binatang }\end{array}$ & Berhasil \\
UJ-P-02 & $\begin{array}{l}\text { Pengujian Memunculkan Objek dengan } \\
\text { Bantuan Marker }\end{array}$ & Berhasil \\
UJ-P-03 & Pengujian Menyuarakan teks Pertanyaan & Berhasil \\
\hline \hline
\end{tabular}

Rangkuman hasil pengujian tingkat kepuasan pengguna dapat dilihat pada Tabel 2. Penilaian karakteristik memiliki skala 1 sampai 6 untuk melihat latar belakang responden. Penilaian kepuasan memiliki skala 1 sampai 3 untuk mempermudah responden menentukan penilaian.

Tabel 2 .

Evaluasi Pengujian Tingkat Kepuasan

\begin{tabular}{clc}
\hline \hline No & \multicolumn{1}{c}{ Pertanyaan } & $\begin{array}{c}\text { Nilai Rata- } \\
\text { rata }\end{array}$ \\
\hline 1 & $\begin{array}{l}\text { Aplikasi memiliki tampilan, warna, dan desain yang } \\
\text { menarik }\end{array}$ & 2.7 \\
2 & $\begin{array}{l}\text { Aplikasi memiliki tata letak button yang mudah } \\
\text { dilihat/dikenal }\end{array}$ & 2.4 \\
3 & $\begin{array}{l}\text { Aplikasi memiliki objek dan background sesuai } \\
\text { dengan kebun binatang }\end{array}$ & 2.4 \\
4 & $\begin{array}{l}\text { Merasakan sensasi nyata seperti berada di kebun } \\
\text { binatang }\end{array}$ & 2.6 \\
5 & $\begin{array}{l}\text { Merasakan sensasi nyata seperti melihat binatang } \\
\text { sungguhan }\end{array}$ & 2.5 \\
6 & $\begin{array}{l}\text { Aplikasi dapat berjalan lancar tanpa adanya lag dan } \\
\text { crash }\end{array}$ & 1.3 \\
7 & $\begin{array}{l}\text { Merasa terbantu dengan adanya tutorial yang } \\
\text { disediakan }\end{array}$ & 1.9 \\
8 & $\begin{array}{l}\text { Merasa nyaman selama menggunakan aplikasi ini } \\
9\end{array}$ & 2.6 \\
\hline \hline
\end{tabular}

\section{KESIMPULAN}

Selama proses perancangan, implementasi, dan pengujian dapat diambil kesimpulan sebagai berikut:

1. Aplikasi telah berhasil menampilkan objek tiga dimensi pada perangkat dengan bantuan marker berukuran yang sesuai. 
2. Aplikasi ini sudah menyediakan skenario pembelajaran yang baik yang didukung dengan hasil tanya jawab pengajar, dan dipadukan dengan perangkat iPad.

3. Pengguna terbantu dengan bantuan berupa suara pertanyaan untuk memahami pertanyaan di setiap skenario, namun kurangnya panduan bermain yang menyebabkan pengguna bingung cara bermain aplikasi pembelajaran.

\section{DAFTAR PUSTAKA}

[1] Unity, "Game engine, tools and multi platfrom," Unity, [Online]. Available: http://unity3d.com/unity. [Accessed 9 april 2014].

[2] P. Inc, "Vuforia Developer Portal," Vuforia, 2016. [Online]. Available: https://developer.vuforia.com/. [Accessed 22 2016].

[3] A. Inc., "Configuring Your Xcode Project," iOS Developer Library, 2015. [Online]. Available: https://developer.apple.com/library/ios/documentation/IDEs/Conceptual/A ppDistributionGuide/Configuring YourApp/Configuring YourApp.html. [Accessed 11 2015].

[4] F. J. D. P. L. B. M. D. Mario Martínez Zarzuela*, "Mobile Serious Game using Augmented reality for Supporting Children's Learning About Animals," Sciencedirect, vol. 25, pp. 375-381, 2013. 